\title{
STRATEGI PEMASARAN PRODUK GADAI EMAS PADA KANTOR PEGADAIAN SYARIAH UNIT PASAR BARU ABEPURA
}

\author{
Fachrudin Fiqri Affandy \\ IAIN Fattahul Muluk Papua \\ affandyjo@gmail.com \\ Siti Jum Iyyah \\ IAIN Fattahul Muluk Papua \\ sitijumiyyah@gmail.com
}

\begin{abstract}
This research discusses about the marketing strategy of gold fiduciary product at Kantor Unit Pegadaian Syariah Pasar Baru Abepura. The aim of this research is to describe the strategies and the obstacles faced by Kantor Pegadaian Syariah Pasar Baru Abepura to attract the community interest. The method used in this research was qualitative descriptive. The research results show that the strategies used can attract the community interest on gold fiduciary product which is one of the alternative funding that does not giving difficulties to the customer to borrow money. Sharia fiduciary does not emphasize on giving the interest. However, Pegadaian Syariah itself obtains the advantages from the cost of service (goods) depositing being pawned. The promotion done by distributing the brochure through social media as well as flyers. From the positioning of the place, it is very strategic because it is in the edge of the road thus the community can reach the office easily. The employees are skillful, kind, polite and the loaning process is fast, as well as the comfortable facilities. The obstacles faced are such as the weather condition which inhibits brochure distribution but can be overcome by using social media intensively.
\end{abstract}

Keywords: Marketing Strategy, Gold Fiduciary Product

\begin{abstract}
ABSTRAK
Strategi Pemasaran Produk Gadai di Kantor Pegadaian Syaraiah Unit Pasar Baru Abepura. Penelitian ini bertujuan untuk mendiskripsikan strategi yang dilakukan dan kendala yang dihadapi Pegadaian Syariah Unit Pasar Baru Abepura untuk menarik minat masyarakat. Metode yang digunakan dalam penelitian ini adalah deskriptif kualitatif. Hasil penelitian menunjukan bahwa strategi yang digunakan mampu menarik minat masyarakat terutama di produk gadai emas ( $\mathrm{rahn}$ ) yang merupakan salah satu allternatif pendanaan yang tidak menyulitkan nasabah untuk mendapatkan pinjaman uang. Pegadaian syariah tidak menekankan pada pemberian bunga. Namun, pegadaian syariah sendiri memperoleh keuntungan dari biaya penitipan jasa (barang) yang digadaikan. Promosi yang dilakukan dengan cara pembagian brosur, melalui media sosial, dan juga pemasangan pamflet. Strategi tempat yang dinilai sangat strategis karena berada dipinggir jalan mampu memberikan kemudahan masyarakat
\end{abstract}


untuk tidak terlalu susah mencari outlet di Pegadaian Syariah sendiri. Para pegawai yang sudah mahir serta ramah dan sopan serta proses peminjaman yang cepat dan juga fasilitas yang membuat nyaman para nasabah. Kendala yang dihadapi seperti cuaca yang menghambat dalam pembagian brosur namun untuk mengatasi kendala tersebut mereka juga memasarkan kepada para nasabah yang datang ke outlet atau kantor.

Kata kunci: Strategi Pemasaran, Gadai Emas

\section{PENDAHULUAN}

\section{Latar belakang}

Pegadaian saat ini merupakan satu-satunya lembaga formal di indonesia yang berdasarkan hukum diperbolehkan melakukan pembiayaan dengan bentuk penyaluran kredit atas dasar hukum gadai. Tugas pokok perum pegadian adalah dapat memenuhi kebutuhan masyarakat dengan pemberian dana pinjaman berdasarkan hukum gadai. Tugas pokok perum pegadian adalah dapat memenuhi kebutuhan masyarakat dengan pemberian dana pinjaman berdasarkan hukum gadai. Tugas tersebut ditujukan untuk membantu masyarakat agar tidak terjerat dalam praktik-praktik lintah darat. Kantor pusat perum pegadaian berkedudukan di Jakarta. Dibantu oleh kantor daerah, kantor perwakilan daerah dan kantor cabang. Jaringan usaha Perum Pegadaian telah meliputi lebih dari 500 cabang yang tersebar di wilayah Indonesia.(Andrie Soemitra,2018:400)

Bersamaan dengan berkembangnya produk keuangan berbasis Syariah yang kian marak di Indonesia, sektor pegadaian juga ikut mengalaminya. Pegadaian Syariah hadir di Indonesia dalam bentuk kerja sama Bank Syariah dengan Perum Pegadaian membentuk Unit Layanan Gadai Syariah di beberapa Kota di Indonesia. Minat masyarakat yang memanfaatkan jasa Pegadaian Syariah cukup besar. Pegadaian Syariah tidak menekankan pada pemberian bunga dari barang yang digadaiakan. Meski tanpa bunga, pegadaian syariah tetap memperoleh keuntungan seperti yang sudah diatur oleh Dewan Syariah Nasional, yang memberlakukan biaya pemeliharaan dari barang yang digadaikan. Biaya itu dihitung dari nilai barang, bukan dari jumlah pinjaman.

Suatu perusahaan yang bergerak dalam bidang apapun baik yang berorientasi terhadap perolehan laba jangka panjang maupun perusahaan nirlaba membutuhkan apa yang disebut dengan pemasaran. Pemasaran adalah suatu seni dan ilmu dalam memilih pasar sasaran dan mendapatkan, menjaga serta menumbuhkan pelanggan dengan menciptakan, menyerahkan dan mengkomunikasikan nilai pelanggan yang unggul. (Hery, 2019:3)

Hal ini kemudian menjadi dasar pegadaian pasar baru abepura untuk merumuskan strategi pemasaran untuk menawarkan produk gadai yang di milikinya yang mana dengan strategi tersebut dapat meningkatkan 
pengetahuan masyarakat terkait pegadaian syariah, begitu juga dengan satu kelebihan dari pegadaian syariah yang tentu saja dapat menarik minat nasabah dengan tidak adanya riba dalam transaksinya.

\section{Kajian Literatur \\ Pengertian Strategi}

Strategi merupakan hal yang sangat penting bagi perusahaan dimana strategi merupakan suatu cara mencapai tujuan dari sebuah perusahaan. Dalam Kamus Besar Bahasa Indonesia (KBBI) disebutkan bahwa istilah strategi adalah suatu ilmu untuk menggunakan sumber daya-sumber daya untuk melaksanakan kebijakan tertentu. Dengan kata lain, strategi yaitu sebuah rencana yang dilakukan untuk mencapai misi perusahaan. (Barry Raiden dan Jay Heizer,2001:28)

\section{Pengertian Pemasaran}

Pengertian pemasaran adalah segala kegiatan yang terkait dengan iklan atau penjualan secara eceran. Bagi sebagian orang, kegiatan pemasaran mencakup sejumlah kegiatan seperti riset pemasaran, penentuan harga, atau perencanaan produk. (Morrisan, 2010:2)

Pemasaran (marketing) bersangkut-paut dengan kebutuhan hidup sehari-hari kebanyakan orang. Melalui proses tersebut, produk atau jasa diciptakan, dikembangkan, dan didistribusikan ke masyarakat. Kebanyakan orang menggangap bahwa pemasaran sama dengan penjualan dan promosi padahal tidaklah demikian. Pada hakikatnya pemasaran adalah kegiatan manusia yang diarahkan untuk memenuhi kebutuhan dan keinginan melalui pertukaran. (Sudaryono,2016:38)

\section{Pengertian Strategi Pemasaran}

Strategi pemasaran pada dasarnya adalah rencana yang menyeluruh, terpadu dan meyatu di bidang pemasaran, yang memberikan panduan tentang kegaiatan yang akan dijalankan untuk dapat tercapainya tujuan pemasaran suatu perusahaan. Dengan kata lain, strategi pemasaran adalah serangkaian tujuan dan sasaran, kebijakan dan aturan yang memberi arah kepada usahausaha pemasaran perusahaan dari waktu ke waktu, pada masing-masing tingkatan dan acuan serta alokasinya, terutama sebagai tanggapan perusahaan dalam menghadapi lingkungan dan keadaan persaingan yang selalu berubah. (Sofjan Assauri, 2018:168)

\section{Pemasaran Dalam Islam}

Pemasaran syariat merupakan sebuah disiplin bisnis strategis yang mengarahkan proses penciptaan, penawaran, dan perubahan values dari satu inisiator ke stakeholders-nya, yang dalam keseluruhan prosesnya sesuai dengan akad serta prinsip-prinsip syariah dan muamalah dalam Islam. Secara umum, kertajaya menyatakan bahwa pemasaran syariah adalah strategi bisnis, yang harus memayungi seluruh aktivitas dalam sebuah perusahaan, meliputi 
seluruh proses, menciptakan, menawarkan, pertukaran nilai, dari seorang produsen, atau salah satu perusahaan, atau perorangan, yang sesuai dengan ajaran Islam. (Buchari Alma dan Donni Juni Priansa, 2014:341)

\section{Indikator Strategi Pemasaran}

Dalam dunia pemasaran selalu terkait dengan yang dinamakan Marketing Mix (bauran pemasaran). Marketing Mix adalah deskripsi dari suatu kumpulan alat-alat yang dapat digunakan oleh manajemen untuk mempengaruhi penjualan. (Nur Rianto Al-Arif, 2012:21)

\section{a. Produk}

Produk adalah sesuatu yang dapat ditawarkan ke pasar untuk diperhatikan, dimiliki, dipakai, atau dikonsumsi sehingga dapat memuaskan keinginan dan kebutuhan. Dalam pengertian luas, produk mencakup apa saja yang bisa dipasarkan, termasuk benda-benda fisik, jasa manusia, tempat, organisasi, dan ide atau gagasan. Jasa adalah produk yang terdiri dari aktivitas, manfaat, atau kepuasan yang dijual, seperti gunting rambut, penyiapan pajak, dan perbaikan rumah. (Sudaryono, 2016:208)

\section{b. Harga}

Harga merupakan penetapan jumlah yang harus dibayar oleh pelanggan untuk memperoleh suatu produk, dan harga suatu barang atau jasa merupakan penentu bagi permintaan pasarnya. Harga dapat mempengaruhi posisi persaingan perusahaan. Faktor-faktor yang perlu dipertimbangkan dalam suatu penetapan harga antara lain: biaya, keuntungan, harga yang ditentukakan oleh pesaing dan perubahan keinginan pasar. (Sofjan Assauri, 2008:361)

\section{c. Promosi (Promotion)}

Promosi adalah suatu komunikasi informasi penjual dan pembeli yang bertujuan untuk merubah sikap dan tingkah laku pembeli, yang sebelumnya tidak mengenal menjadi menggenal sehingga menjadi pembeli dan tetap menggingat produk tersebut. Pemasar melakukan promosi untuk mengkomunikasikan informasi tentang produk mereka dan mempengaruhi konsumen untuk membelinya. Promosi sebagai upaya memperkenalkan produk dan jasa agar bisa dikenal dan diterima publik. (Djaslim Saladin, 1991:66)

\section{d. Distribution}

Dalam sektor jasa, distribusi didefinisakan sebagai setiap sarana yang meningkatkan keberadaan atau kenikmatan suatu jasa yang menambah penggunaannya, baik dengan mempertahankan pemakai yang ada ataupun menarik pemakai baru. (Murti Sumarni, 1997:269) Unsur Place dalam jasa merupakan gabungan antara lokasi dan kepuasan saluran distribusi, dalam hal ini berhubungan dengan cara penyampaian jasa kepada konsumen. Distribusi adalah proses yang membuat suatu produk 
atau layanan tersedia untuk digunakan atau dikonsumsi oleh konsumen pengguna atau bisnis, menggunakan cara langsung, atau menggunakan cara tidak langsung melalui perantara. (M. Suyanto, 2018:277)

\section{e. Pelaku (People)}

People adalah semua pelaku yang memainkan peranan dalam penyajian jasa sehingga dapat mempengaruhi persepsi pembeli. Elemenelemen dari people adalah pegawai perusahaan, konsumen, dan konsumen lain dalam lingkungan jasa. Semua tindakan karyawan bahkan cara berpakaian dan penampilan karyawan mempunyai pengaruh terhadap persepsi konsumen atau keberhasilan penyampaian jasa (service encounter). Dalam hubungannya dengan pemasaran jasa, maka people yang berfungsi sebagai service provider sangat mempengaruhi kualitas jasa yang diberikan. Pencapaian kualitas yang terbaik menyebabkan para pegawai baru harus dilatih agar menyadari betapa pentingnya pekerjaan tersebut dengan memberikan kepuasan kepada konsumen dalam memenuhi kebutuhannya.

Untuk organisasi jasa, service people biasanya memegang jabatan ganda, yaitu mengadakan jasa dan menjual jasa tersebut. Melalui pelayanan yang baik, cepat, ramah, teliti dan kesetian pelanggan terhadap perusahaan yang akhirnya akan meningkatkan nama baik perusahaan. (Didin Fatihudin dan Anang Firmansyah, 2019:189)

\section{f. Proses (Process)}

Proses adalah semua procedure actual, mekanisme, dan aliran aktivitas yang digunakan untuk menyampaikan jasa. Elemen proses ini mempunyai arti suatu upaya perusahaan dalam menjalankan dan melaksanakan aktivitas untuk memenuhi kebutuhan dan kegiatan konsumenya. Untuk perusahaan jasa, kerja sama antara pemasaran dan operasional sangat penting dalam elemen proses ini, terutama dalam melayani segala kebutuhan dan keinginan konsumen. Jika dilihat dari sudaut pandang konsumen, maka kualitas jasa diantaranya dilihat bagaimana jasa menghasilkan fungsinya. Proses dalam jasa merupakan faktor utama dalam bauran pemasaran jasa seperti pelanggan jasa akan sering merasakan sistem penyerahan jasa sebagai bagian dari jasa itu sendiri. (Didin Fatihudin dan Anang Firmansyah, 2019:189)

\section{g. Physical Evidence (Bukti Fisik)}

Physical evidence (bukti fisik) ini merupakan suatu hal yang secara turut mempengaruhi keputusan konsumen untuk membeli dan menggunakan produk jasa yang ditawarkan. "Unsur-unsur yang termasuk didalam bukti fisik antara lain lingkungan fisik, dalam hal ini bangunan fisik, peralatan, perlengkapan, logo, warna, dan barang-barang lainnya yang disatukan dengan service yang diberikan seperti tiket, sampul, label, dan lain sebagainya. (Didin Fatihudin dan Anang Firmansyah, 2019:189) 


\section{Teori Kendala}

Teori kendala (theory of counstaint-TOC) merupakan teknik strategis untuk membantu perusahaan secara efektif memperbaiki CSF (ukuran atas semua aspek kinerja perusahaan yang penting untuk memperoleh keunggulan kompetitif, yang merupakan penentu keberhasilan perusahaan) yang sangat penting. Waktu siklus, yakni tingkat kecepatan bahan baku diubah menjadi produk jadi. "TOC membantu menemukan dan menghilangkan kemacetan produksi- tempat-tempat dimana barang satengah jadi (masih dalam proses) cenderung terakumulasi karena barang-barang tersebut menunggu untuk diproses lebih lanjut-pada proses produksi.

Teori Kendala adalah metode, pendekatan dan alat yang digunakan untuk memaksimalkan pendapatan dengan cara mengidentifikasi kendala yang terjadi serta menganalisis cara untuk mengatasi kendala tersebut. (Edward J. Blocher dan Kung H. Chen, 2007:22)

\section{METODE PENELITIAN}

Penelitian ini adalah penelitian kualitatif dimana menurut Bogdan dan Taylor menjelaskan bahwa penelitian kualitatif adalah salah satu prosedur penelitian yang menghasilkan data deskriptif berupa ucapan atau tulisan dan perilaku orang-orang yang diamati.(V. Wiratna Sujarweni, 2018:19).

\section{SUBJEK DAN OBJEK PENELITIAN}

Subjek adalah seseorang atau sesuatu yang mengenainya ingin diperoleh keterangan atau orang pada latar penelitian yang dimanfaatkan untuk memberikan informasi tentang situasi dan kondisi latar penelitian.

Subjek dalam penelitian ini adalah Bagian Pemasaran dan Nasabah di Pegadaian Syariah Unit Pasar Baru Abepura. Objek adalah apa yang akan diselidiki selama penelitian.

Objek dalam penelitian ini adalah Strategi Pemasaran Produk Gadai di Kantor Pegadaian Syariah Unit Pasar Baru Abepura.

\section{JENIS DATA DAN TEKNIK ANALISIS DATA}

1. Jenis data

Jenis data yang digunakan dalam penelitian ini adalah data primer dan data sekunder

2. Teknik analisis data
a. Observasi
b. Wawancara
c. Dokumentasi 


\section{TEKNIK ANALISIS}

Teknik analisis data selama penelitian ini menggunakan metode:

1. Observasi

Observasi merupakan penelitian dengan melakukan pengamatan menyeluruh pada sebuah kondisi tertentu. Tujuan penelitian ini untuk mengamati dan memahami perilaku kelompok orang maupun individu pada keadaan tertentu. (V Wiratna Sujarweni, 2015:89)

2. Wawancara

Wawancara merupakan salah satu teknik yang dapat digunakan untuk mengumpulkan data penelitian. Secara sederhana dapat dikatakan bahwa wawancara (interview) adalah suatu kejadian atau suatu proses interaksi antara pewawancara (interviewer) dan sumber informasi atau orang yang diwawancarai (interviewee) melalui komunikasi langsung. (Yusuf Muri, 2004:372)

3. Dokumentasi

Dokumen merupakan rekaman kejadian masa lalu yang ditulis atau dicetak mereka dapat berupa catatan anekdot, surat, buku harian, dan dokumendokumen. Dokumen kantor termasuk lembaran internal, komunikasi bagi publik yang beragam, file siswa dan atau pegawai, deskripsi program dan data statistik. (Uhar Suhasaputri, 2018:215)

\section{HASIL DAN PEMBAHASAN}

\section{HASIL}

\section{A. Strategi Pemasaran Produk Gadai Emas Di Kantor Pegadaian Syariah Unit Pasar Baru Abepura}

a. Strategi Produk

Berdasarkan hasil wawancara strategi produk yang dilakukan oleh Pegadaian Syariah Unit Pasar Baru Abepura memberikan dana pinjaman yang cepat tanpa harus menjual emas dengan hanya menggadaikan emas, siapun boleh menjadi nasabah baik muslim maupun non muslim.

b. Strategi Harga

Berdasarkan hasil wawancara strategi harga yang diberikan sudah sesuai dengan aturan pemerintah. Namun, Pegadaian Syariah Unit Pasar Baru Abepura sendiri tidak menerapkan sistem bunga, tetapi hanya dibebankan pada biaya penitipan jasa.

c. Strategi Promosi

Berdasarkan hasil wawancara, strategi promosi yang dilakukan oleh Pegadaian Syariah Unit Pasar Baru Abepura melakukan promosi dengan pembagian brosur, pemasangan spanduk, serta melalui media online seperti facebook dan whatsapp. 
d. Startaegi Tempat

Berdasarkan hasil wawancara strategi tempat yang dilakukan oleh Pegadaian Syariah Unit Pasar Abepura memiliki tempat atau lokasi yang strategis, berada di pinggir jalan serta dekat dengan toko dan kantor.

e. Strategi People

Berdasarkan hasil wawancara strategi people yang dilakukan oleh Pgadaian Syariah Unit Pasar Baru Abepura para karryawan yang sudah mahir dalam memasarkan produk, berpakaian ramah dan rapi serta karyawan yang juga merangkap sebagai tim pemasar.

f. Strategi Proses

Berdasarkan hasil wawancara strategi proses yang dilakukan oleh Pegadaian Syariah Unit Pasar Baru Abepura proses gadai tidak mempersulit para nasabah dengan membawa KTP dan barang yang akan digadai nasabah sudah mendapatkan pinajaman uang serta proses yang juga cepat.

g. Strategi Physical Evidence

Berdasarkan hasil wawancara strategi physical evidence yang dilakukan oleh Pegadaian Syariah Unit Pasar Baru Abepura, ruangan yang bersih, tersedia tempat duduk, meja serta alat pendingin ruangan.

\section{B. Kendala Dalam Memasarkan Produk Gadai Emas Di Kantor Pegadaian Syariah Unit Pasar Baru Abepura}

Berdasarkan hasil wawancara, pihak Pegadaian Syariah Unit Pasar Baru Abepura memiliki kendala yaitu cuaca yang tidak menentu. Apabila terjadi hujan maka tidak dapat membagikan brosur dan penyelesaian yang dilakukan adalah dengan menawarkan produk gadai emas kepada nasabah yang datang ke kantor, melakukan promosi melalui media sosial yang dimiliki oleh Pegadaian Syariah, serta memberikan pelayanan yang baik kepada nasabah. Pihak Pegadaian mengambil alternatif memasarkan produk tersebut agar nasabah menjadi nyaman dan akan kembali lagi untuk bertransaksi di Pegadaian Syariah Unit Pasar Baru Abepura.

\section{PEMBAHASAN}

1. Strategi Pemasaran Produk Gdaia Emas Di Kantor Pegadaian Syariah Unit Pasar Baru Abepura

a. Produk

Strategi yang dilakukan Pegadaian Syariah tidak ada strategi khusus, namun yang mereka lakukan memberikan pinjaman dengan proses yang cepat dalam menggadaikan emas. Nasabah tidak perlu untuk menjual emas mereka dan dapat mengambil kembali emas mereka saat uang yang mereka punya sudah mencukupi. Penelitian terdahulu yang dilakuka oleh Lia Rofiani yang berjudul Strategi 
Pemasaran Pembiayaan Gadai Emas Di Bank Syariah Mandiri Cabang Pembantu Gubug dengan penelitian ini dari segi teori sudah selaras yaitu adanya produk yang ditawarkan kepada masyarakat. Namun, dalam strategi produk di Bank Syariah Mandiri Cabang Pembantu Gubug mereka melakukan strategi khusus seperti adanya layanan gratis cuci emas, dan juga bekerja sama dengan toko emas disini toko emas Sinar Mulya dan Wisma Cahaya, dimana produk gadai emas bukan hanya untuk memenuhi kebutuhan masyarakat yang konsumtif tetapi juga para pengusaha untuk modal usaha mereka. Sedangkan strategi yang dilakukan Pegadaian Syariah tidak ada strategi khusus namun yang mereka lakukan memberikan pinjaman dala proses yang cepat dalam menggadaikan emas sehingga para nasabah tidak perlu untuk menjual emas mereka dan dapat mengambil kembali emas mereka saat uang yang mereka punya sudah mencukupi.

b. Strategi Harga

Dalam penentuan harga sangatlah penting karena penentuan harga bisa menentukan laku tidaknya suatu produk. Penentuan harga yang di lakukan Pegadaian Syariah Unit Pasar Baru Abepura berdasarkan hasil wawancara tidak adanya sistem bunga hanya dikenakan biaya jasa, penentuan harga juga sudah sesuai dengan akad syariah. Penelitian ini juga selaras dengan penelitian terdahulu yang dilakuka oleh Lia Rofiani yang berjudul Strategi Pemasaran Pembiayaan Gadai Emas Di Bank Syariah Mandiri Cabang Pembantu Gubug. Adanya harga yang dibebankan kepada dari gadai emas yang dilakukan yakni adanya biaya titip yang dikenakan kepada nasabah dalam pembiayaan gadai emas yang dilakukan.

c. Strategi Promosi

Strategi promosi merupakan sarana yang dilakukan oleh perusahaan untuk menarik minat nasabah baru maupun menarik nasabah yang lama dengan produk yang mereka tawarkan. Strategi yang dilakukan Pegadaian Syariah Unit Pasar Baru Abepura berdasarkan hasil wawancara yaitu dengan pembagian brosur yang dilakukan disekitaran daerah Abe maupun tempat keramaian pembagian brosur ke kios-kios perumahan dan toko melalui media online juga seperti facebook dan whattsap. Penelitian Lia Rofiani yang berjudul Strategi Pemasaran Pembiayaan Gadai Emas Di Bank Syariah Mandiri Cabang Pembantu Gubug dan teori yang dilakukan selaras dengan penelitian ini dimana promosi yang mereka lakukan membagikan brosur dan juga setiap pegawai bertindak sebagai tim pemasar produk gadai emas ini.

d. Strategi Tempat

Penentuan lokasi merupakan hal penting dalam pemasaran dimana dengan penentuan lokasi yang bagus dan juga strategis dapat 
menjadikan masyarakat mudah untuk menemukan lokasi perusahaan. dari hasil wawancara dapat dilihat bahwa lokasi Pegadaian Syariah Unit Pasar Baru bertempat di JL. Baru Pasar Yotefa, dimana kawasan ini merupakan lintasan ramai penduduk yang berdekatan dengan toko-toko dan juga kantor-kantor. Lokasi yang strategis dekat dengan jalan raya memudahkan masyarakat sehingga tidak perlu susah lagi untuk menemukan kantor Pegadaian Syariah Unit Pasar Baru Abepura. Dalam penelitian terdahulu oleh Lia Rofiani yang berjudul Strategi Pemasaran Pembiayaan Produk Gadai Emas Di Bank Syariah Mandiri Cabang Pembantu Gubug dengan teori yang ada selaras yaitu penentuan lokasi yang strategis dan juga merupakan kawasan ramai sehingga masyarakat lebih mudah menjangkau lokasi perusahaan.

e. Strategi People

Para karyawan di Pegadaian Syariah Unit Pasar Baru Abepura dalam strategi people dengan memberikan kenyaman kepada nasabah dengan tampilan mereka yang rapi, ramah dan sopan serta mahir dalam memasarkan produk hal ini yang menjadikan nasabah senang untuk datang atau bertransaksi di Pegadaian Syariah Unit Pasar Baru Abepura. Penelitian yang dilakukan oleh Lia Rofiani yang berjudul Strategi Pemasaran Pembiayaan Gadai Emas Di Bank Syariah Mandiri Cabang Pembantu Gubug. Penelitian ini dan teori yang dipakai sudah selaras yakni dalam pemasaran produk para karyawan berpakaian rapi, serta ramah dan sopan dan juga pandai dalam memasarkan produk sehingga nasabah merasakan kenyamanan dalam bertransaksi.

\section{f. Strategi Proses}

Proses gadai di Pegadaian Syariah Unit Pasar Baru Abepura yaitu nasabah datang membawa KTP serta barang yang akan digadai setelah itu mengisi formulir dan menyerahkan barang yang akan digadai kepada pihak penaksir, dalam prosesnya pihak Pegadaian Syariah juga menekankan waktu sekitar 15 menit memproses setiap transaksi gadai sehingga nasabah tidak perlu menunggu lama. Dalam penelitian terdahulu Lia Rofiani yang berjudul Strategi Pemasaran Pembiayaan Gadai Emas Di Bank Syariah Mandiri Cabang Pembantu Gubug. Hasil penelitian dan teori yang dipakai selaras yakni dalam proses yang dilakukan sama yaitu nasabah datang membawa KTP dan barang jaminan kemudian mengisi formulir serta menyerahkan kepada pihak penaksir.

g. Physical Evidence

Strategi Physical Evidence adalah strategi yang mempengaruhi minat nasabah dengan adanya bukti fisik atau sarana fisik yang diberikan oleh Pegadaian Syariah Unit Pasar Baru Abepura kepada para nasabahnya dengan adanya kursi untuk duduk, ruangan yang sudah dilengkapi dengan pendingin ruangan dan meja untuk nasabah mengisi 
formulir gadai emas. Dalam penelitian terdahulu Lia Rofiani yang berjudul Strategi Pembiayaan Pemasaran Produk Gadai Emas Di Bank Syariah Mandiri Cabang Pembantu Gubug, dengan teori yang dipakai selaras yakni adanya fasilitas yang diberikan untuk kenyamanan nasabah seperti kursi, pendingin ruangan dan juga meja serta adanya konter layanan gadai.

\section{Kendala dalam Memasarkan Produk Gadai Emas Di Kantor Pegadaian Syariah Unit Pasar Baru Abepura}

Kendala merupakan segala sesuatu yang dapat menghambat sebuah perusahaan dalam mencapai tujuan perusahaan kendala bukan hanya terjadi terjadi di luar perusahaan namun juga terjadi didalam perusahaan itu sendiri. Kendala yang dialami oleh pihak Pegadaian Syariah Unit Pasar Baru sendiri kendala internal tidak ada tetapi kendala yang biasa terjadi seperti faktor cuaca yang menjadi kendala ketika akan membagi brosur. Penelitian terdahulu oleh Lia Rofiani yang berjudul Strategi Pembiayaan Pemasaran Produk Gadai Emas Di Bank Syariah Mandiri Cabang Pembantu Gubug dan teori yang dipakai selaras yakni kendala yang dihadapi oleh Bank Syariah Mandiri Cabang Pembantu Gubug, Masyarakat masih kurang familiar dengan produk gadai emas di Bank sehingga masyarakat lebih sering gadai di Pegadaian umum, asumsi yang berkembang di masyarakat bahwa prosedur gadai di Bank berbelit-belit cara mengatasi masalah di Bank Syariah Mandiri Cabang Pembantu Gubug sendiri yaitu meningkatkan kegiatan pengenalan produk ke institusi serta menambah tenaga marketing dalam pemasaran produk gadai emas, namun kendala yang dihadapi oleh Pegadaian Syariah Unit Pasar Baru adanya faktor cuaca yang menghambat dalam kegiatan mambegi brosur namun cara pegadaian menyelesaikan masalah tersebut yaitu tetap memberikan pelayanan yang baik kepada nasabah serta menawarkan produk gadai kepada para nasabah yang datang ke outlet atau kantor pegadaian syariah unit pasar baru abepura.

\section{KESIMPULAN DAN SARAN \\ Kesimpulan}

1. Berdasarkan hasil wawancara terkait strategi pemasaran produk gadai emas di Pegadaian Syariah Unit Pasar Baru Abepura dapat disimpulkan bahwa dalam strategi pemasaran produk gadai emas di Kantor Pegadaian Syariah Unit Pasar Baru Abepura, memberikan kemudahan kepada masyarakat dalam mendapatkan pinjaman tanpa harus menjual emas proses peminjaman juga cepat tidak dipersulit. Dalam strategi harga, harga yang didapatkan juga termasuk murah serta tidak adanya sistem bunga dan hanya dikenakan biaya titip. Strategi promosi yang dilakukan melalui pembagian brosur, media online seperti facebook dan whatsap serta pemasangan spanduk. Strategi tempat atau lokasi sangat strategis karena 
berada dipinggir jalan dekat dengan kantor-kantor dan juga toko serta merupakan lintasan yang ramai. Strategi people para karyawan juga sudah mahir dalam memasarkan produk, tampilan mereka rapi serta ramah dalam melayani nasabah. Strategi proses dalam gadai tidak dipersulit hanya membawa KTP, serta barang yang akan digadaikan nasabah. Setelahnya nasabah mendapatkan uang pinjaman. Strategi bukti fisik seperti adanya Air Conditioner tempat duduk dan ruangan yang bersih.

2. Kendala dalam pemasaran produk gadai emas yaitu, dari segi external seperti faktor cuaca yang menyulitkan para karyawan dalam membagi brosur, tetapi dalam mengatasi masalah tersebut para karyawan memberikan pelayanan yang terbaik bagi nasabah, serta memasarkan produk kepada nasabah yang datang ke outlet atau kantor pegadaian syariah unit pasar baru Abepura.

\section{Saran}

Pihak Pegadaian perlu memberikan sosialisasi kepada nasabah terkait aplikasi Pegadaian Syariah, sehingga nasabah mudah dalam bertransaksi online. Pemberian souvenir seperti bolpoin atau gelas dapat membuat nasabah merasa senang dan mau kembali lagi untuk menggadaikan emas di Pegadaian Syariah Unit Pasar Baru Abepura.

Penelitian ini perlu ditindaklanjuti dengan mengambil objek strategi pemasaran. Peneliti selanjutnya dapat menggali secara mendalam tentang efektivitas penerapan strategi pemasaran produk, terlebih dimasa pandemi seperti saat ini.

\section{DAFTAR REFRENSI}

Assauri, Sofjan. Manajemen Pemasaran. Cet ke-16. Depok: PT Raja Grafindo Persada, 2018.

Alma Buchari dan Donni Juni Priansa. Manajemen Bisnis Syariah, Alfabeta: Bandung, 2014.

Arif Nur Rianto Al. Dasar-Dasar Pemasaran Bank Syariah, Alfabeta: Bandung, 2012.

Fatihudin Didin dan Anang Firmansyah. Pemasaran Jasa, Yogyakarta: Penerbit Deepublish, 2019.

Hery. Manajemen Pemasaran. Jakarta:PT Grasindo, 2019.

Morrisan. Periklanan Komunikasi Pemasaran Terpadu. Jakarta:Peranamedia Grup, 2008.

Muri, Yusuf. Metode Penelitian Kualitatif, Kuantitatif dan Penelitian Gabungan. Jakarta: Kencana, 2004. 
Suharsaputra, Uhar. Metode Penelitian Kualitatif, Kuantitatif, dan Tindakan. Cet ke-3. Bandung: PT Refika Aditama, 2018.

Seomitra, Andri. Bank dan Lembaga Keuangan Syariah. Cet ke-9 Jakarta: PERANAMEDIA GROUP, 2009.

Sudaryono. Manajemen Pemasaran Teori dan Implementasi. Yogyakarta: Penerbit ANDI, 2016.

Sujarweni, V Wiratna. Metodologi Penelitian Bisnis dan Ekonomi. Yogyakarta: PT PUSTAKA BARU, 2015.

Saladin Djaslim, Unsur-Unsur Inti Pemasaran Dan Manajemen Pemasaran, Bandung: Mandar Maju, 1991.

Sumarni Murti, Marketing Perbankan, Yogyakarta: Liberty, 1997.

M, Suyanto. Muhammad Marketing Strategy, Yogyakarta: ANDI OFFSET, 2018. 